\title{
PROFIL KESALAHAN SISWA DALAM MENYELESAIKAN SOAL MATRIKS BERDASARKAN JENIS KELAMIN DI SMA NEGERI 7 PALU
}

\author{
Fausan $^{1)}$, Gandung Sugita ${ }^{2)}$, Sukayasa ${ }^{3)}$ \\ fausanojan96@gmail.com ${ }^{1)}$,gandungplw@yahoo.co.id ${ }^{2)}$,Sukayasa08@yahoo.co.id ${ }^{3)}$
}

\begin{abstract}
Abstrak: Penelitian ini merupakan penelitian kualitatif yang bertujuan untuk memperoleh profil kesalahan yang dilakukan siswa dalam menyelesaikan soal matriks berdasarkan jenis kelamin di SMA Negeri 7 Palu. Data dikumpulkan dengan cara metode tes dan wawancara. Subjek penelitian terdiri dari satu siswa laki-laki (SH) dan satu siswa perempuan (DS). Hasil Penelitian menunjukkan bahwa kesalahan konseptual yang dilakukan siswa laki-laki (SH) yaitu : 1) kesalahan tidak memahami konsep rumus perkalian matriks, 2) kesalahan konsep perkalian matriks, 3) kesalahan tidak menerapkan rumus invers, 4) kesalahan konsep invers matriks dan 5) kesalahan konsep adjoin. Kesalahan prosedural yang dilakukan siswa laki-laki berupa 1) kesalahan dalam melakukan perhitungan, 2) kesalahan tidak menyederhanakan dan 3) kesalahan tidak menuliskan tanda operasi pada matriks. Sedangkan kesalahan konseptual yang dilakukan siswa perempuan (DS) yaitu: 1) kesalahan tidak memahami konsep rumus perkalian matriks, 2) kesalahan konsep perkalian matriks, 3) kesalahan konsep adjoin dan 4) kesalahan konsep invers matriks. Kesalahan prosedural yang dilakukan siswa perempuan berupa 1) kesalahan dalam melakukan perhitungan. Siswa laki-laki banyak melakukan kesalahan dari pada siswa perempuan dikarenakan, siswa lakilaki tidak teliti dan terburu-buru dalam menyelesaikan soal matriks. Sedangkan siswa perempuan tidak terlalu banyak melakukan kesalahan dikarenakan cenderung lebih teliti dan cermat dalam menyelesaikan soal matriks.
\end{abstract}

Kata kunci: Profil Kesalahan, Jenis Kelamin dan Matriks

\begin{abstract}
This research is a qualitative research which aims to obtain a profile of errors students make in solving matrix problems based on sex in SMA 7 Palu. Data was collected by means of test and interview methods. The research subjects consisted of one male student ( $\mathrm{SH}$ ) and one female student (DS). The results showed that the conceptual errors made by male students ( $\mathrm{SH})$ were: 1) errors not understanding the concept of matrix multiplication formula, 2) errors in matrix multiplication concepts, 3) errors not applying inverse formulas, 4) inverse matrix concept errors and 5 ) the error of the adjoin concept. Procedural errors made by male students in the form of 1) errors in making calculations, 2) errors do not simplify and 3 ) errors do not write the operation mark on the matrix. Whereas the conceptual errors made by female students (DS) are: 1) errors do not understand the concept of matrix multiplication formula, 2) errors in the concept of matrix multiplication, 3 ) errors in adjoining concepts and 4) inverse matrix concept errors. Procedural errors made by female students in the form of 1) errors in carrying out calculations. Male students make a lot of mistakes than female students because, male students are not careful and in a hurry to solve the matrix problem. Whereas female students don't make too many mistakes becausethey tend to be more thorough and careful in solving matrix problems.
\end{abstract}

Keywords: Error Profile, Gender and Matrix

Matematika merupakan mata pelajaran yang selalu ada di setiap jenjang pendidikan mulai dari jenjang pendidikan dasar hingga pendidikan tinggi selalu ada kaitannya dengan matematika. Perkembangan pesat di bidang teknologi informasi dan komunikasi saat ini dilandasi oleh perkembangan matematika yang berguna bagi kehidupan manusia dan mempunyai peran penting dalam berbagai disiplin ilmu serta dapat memajukan daya pikir manusia. Oleh karena itu, matematika sebagai ilmu dasar yang memiliki peranan sangat penting perlu dikuasai dengan baik oleh siswa (Susanto, 2013:185). Namun kenyataanya, Asrori (2007:241) menyatakan bahwa pelajaran matematika seringkali dirasakan sulit oleh 
siswa sehingga cenderung tidak disenangi siswa bahkan tidak jarang siswa yang memandang pelajaran matematika sebagai momok yang menakutkan. Akibatnya, tidak sedikit siswa yang kurang tertarik untuk mempelajari matematika dan akhirnya menjadikan siswa mengalami hambatan dalam belajar matematika.

Agar siswa mudah memahami pelajaran matematika di sekolah maka diharapkan guru hendaknya dapat memberikan kesempatan kepada semua siswa untuk memahami matematika dalam kehidupannya. Akan tetapi, masih banyak siswa yang melakukan kesalahan dalam mengerjakan soal matematika dan itulah yang akan menjadi masalah bagi siswa untuk dapat menerapkan matematika dalam kehidupannya.

Masalah yang perlu menjadi perhatian berkaitan dengan pelajaran matematika adalah banyaknya kesalahan yang dilakukan siswa dalam menyelesaikan soal matematika. Kesalahan-kesalahan umum yang sering dilakukan siswa dalam menyelesaikan soal-soal matematika menurut Newman (1977) dibedakan menjadi lima tipe kesalahan yaitu 1) reading error (kesalahan membaca), 2) comprehension error (kesalahan memahami), (3) transformation error (kesalahan dalam transformasi), (4) process skills error (kesalahan dalam keterampilan proses), (5) encoding error (kesalahan pada notasi). Kastolan (1992) membedakan jenis-jenis kesalahan menjadi 2 yakni kesalahan konseptual dan kesalahan prosedural. Wulandari (2018) menyatakan bahwa kesalahan yang dapat dilakukan siswa saat menyelesaikan soal matematika diantaranya adalah 1) kesalahan konsep, 2) kesalahan prinsip, 3) kesalahan operasi, 4) kesalahan karena kecerobohan. Menurut Wahbi (2015) kesalahan sebenarnya merupakan hal yang wajar dilakukan, namun apabila kesalahan yang dilakukan cukup banyak dan berkelanjutan, maka diperlukan penanganan. Begitu juga dalam mempelajari matematika, merupakan suatu hal yang wajar apabila dalam menyelesaikan soal matematika siswa melakukan kesalahan. Namun apabila kesalahankesalahan yang muncul tidak segera mendapat perhatian dan tindak lanjut, akan berdampak buruk bagi siswa.

Matriks adalah salah satu cabang dari aljabar yang diajarkan dalam bidang matematika dan merupakan materi yang diajarkan di tingkat sekolah menengah atas (SMA) yang dianggap tidak mudah bagi siswa. Peneliti telah melakukan observasi dan wawancara ke beberapa sekolah untuk mencari informasi mengenai kesalahan-kesalahan siswa dalam menyelesaikan soal matriks. Salah satu sekolah yang banyak melakukan kesalahan dalam menyelesaikan soal matriks adalah SMA Negeri 7 Palu.

Berdasarkan hasil dialog peneliti dengan guru diperoleh informasi bahwa, dalam pembelajaran di kelas hampir semua siswa memperhatikan dan aktif namun ada sebagian siswa tidak memperhatikan dan hanya pasif dalam pembelajaran. Selain itu setelah guru memberikan pembelajaran, guru selalu memberikan kuis atau tes kepada siswa dan hasilnya ada siswa yang melakukan kesalahan saat mengerjakan kuis atau tes itu. Salah satu materi yang dimana siswa melakukan kesalahan yaitu materi matriks dan kesalahan yang dilakukan oleh siswa laki-laki berbeda dengan siswa perempuan dalam penyelesaiannya. Kesalahan-kesalahan siswa dalam menyelesaikan soal matriks itu dapat diklasifikasikan diantaranya kesalahan pemahaman konsep baris dan kolom pada matriks, kesalahan operasi perkalian antara baris dan kolom, kesalahan rumus untuk menentukan invers pada matriks ordo $3 \times 3$, kesalahan dalam mengerjakan determinan dan invers matriks, dan kesalahan dalam menghitung nilai matriks sehingga mengakibatkan pekerjaan siswa kurang maksimal dan prestasi hasil belajar siswa semakin menurun.

Setiap individu dalam menyelesaikan soal memiliki proses berpikir yang berbedabeda, terutama jika dilihat dari perbedaan jenis kelamin. Fakta bahwa secara umum berbagai perbedaan sosial dan biologis antara laki-laki dan perempuan itu mempengaruhi 
proses pembelajaran (Jensen, 2008). Fredmen (Oktavianti, 2016) mengemukakan bahwa anak laki-laki lebih unggul dari pada anak perempuan dalam bidang aljabar, geometri, dan penalaran. Menurut Krutetskii (1976), bahwa dalam berpikir siswa perempuan lebih unggul dalam ketepatan, ketelitian, kecermatan, dan ketaksamaan, sedangkan siswa laki-laki cenderung kurang teliti, terburu-buru, dan menyelesaikan sesuatu dengan cara singkat. Menurut Susento (2006) perbedaan jenis kelamin bukan hanya berakibat pada perbedaan kemampuan dalam matematika, tetapi cara memperoleh pengetahuan matematika juga terkait dengan perbedaan jenis kelamin. Hal ini menunjukkan adanya perbedaan dalam proses berpikir individu ditinjau dari perbedaan jenis kelamin. Oleh karena itu, untuk mencegah kesalahan berkelanjutan yang dilakukan siswa perlu adanya penanganan lebih lanjut, agar mendapatkan gambaran yang jelas atas kesalahan-kesalahan siswa dalam menyelesaikan soal, sehingga kesalahan-kesalahan yang dilakukan oleh siswa dapat diminimalisir dan tidak terulang kembali.

Berdasarkan latar belakang tersebut, maka rumusan masalah dalam penelitian ini adalah bagaimana profil kesalahan yang dilakukan siswa dalam menyelesaikan soal matriks berdasarkan jenis kelamin di SMA Negeri 7 Palu ??

\section{METODE PENELITIAN}

Jenis penelitian ini adalah penelitian kualitatif dengan pendekatan deskriptif kualitatif. Subjek penelitian ini adalah siswa kelas XI SMA Negeri 7 Palu. Adapun pemilihan subjek berdasarkan kriteria yaitu: 1) siswa laki-laki dan siswa perempuan yang banyak melakukan kesalahan, 2) kesalahan yang dilakukan bervariasi, 3) kemampuan siswa laki-laki dan perempuan dapat berkomunikasi dengan baik, dan 4) berdasarkan rekomendasi dari guru matematika SMA Negeri 7 Palu. Siswa yang terpilih sebagai subjek yaitu untuk siswa laki-laki berinisial SH dan untuk siswa perempuan berinisial DS. Teknik pengumpulan data pada penelitian ini adalah tes dan wawancara. Instrumen penelitian ini adalah instrumen utama yaitu peneliti sendiri dan instrumen pendukung yaitu tes soal matriks dan pedoman wawancara. Analisis data dalam penelitian ini mengacu pada analisis data kualitatif menurut Miles, Hubermen dan Saldana (2014) yaitu Data Condensation, Data Display, dan Drawing and Verifying Conclusions.

\section{HASIL PENELITIAN}

Dipilih satu kelas yang digunakan sebagai subjek penelitian yaitu kelas XI IPA 4 yang terdiri dari 23 siswa, siswa laki-laki berjumlah 9 orang dan siswa perempuan berjumlah 12 orang. Peneliti memilih kelas tersebut sebagai subjek penelitian karena kelas ini memiliki prestasi belajar matematika yang lebih rendah dibandingkan dengan kelas yang lain. Setelah dilakukan tes 1 yang berjumlah 2 nomor yang masing-masing untuk nomor 1 ada 2 bagian dan nomor 2 ada 3 bagian, maka terpilih siswa laki-laki berinisial SH dan siswa perempuan berinisial DS, kemudian dilakukan tes 2. Uji kredibilitas dilakukan dengan menggunakan triangulasi waktu yaitu memberikan tes 1 dan tes 2 kepada subjek penelitian dalam waktu yang berbeda dengan tes 1 dan tes 2 merupakan tes yang setara. Masing-masing subjek menyelesaikan kedua tes tersebut dan telah kredibel, data yang dianalisis dalam penelitian ini adalah data pada tes 1 .

\section{Jawaban Subjek Laki-laki (SH) Pada nomor 1 bagian a}

Jawaban subjek SH dalam menyebutkan informasi yang diketahui dan ditanyakan pada M1, ditampilkan sebagai berikut: 


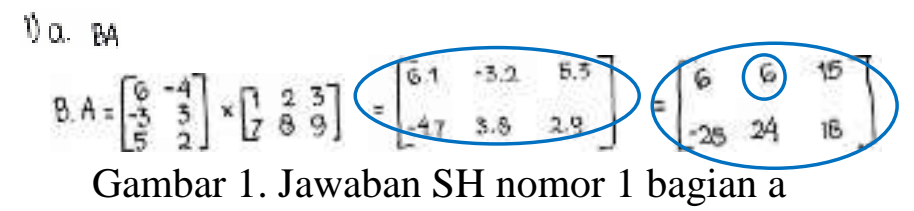

Peneliti melakukan wawancara untuk memperoleh informasi lebih lanjut tentang kesalahan yang dilakukan SH. Berikut petikan hasil wawancara peneliti dengan SH :

SH1 $005 \mathrm{P}$ : Coba jelaskan jawaban kamu nomor 1 bagian a ?

SH1 $006 \mathrm{~S}$ : Pada soal disini matriks B dan A sudah diketahui (sambil menunjuk), terus penyelesaian saya, saya kalikan baris dengan kolom jadi $6 \times 1,-4 \times 7,-3 \times$ $2,3 \times 8,5 \times 3,2 \times 9$.

SH1 $007 \mathrm{P}$ : Terus diapakan lagi dek?

SH1 $008 \mathrm{~S} \quad$ : Terus kita selesaikan menjadi $\left[\begin{array}{ccc}6 & 6 & 15 \\ -28 & 24 & 18\end{array}\right]$.

SH1 $009 \mathrm{P}$ : Oh, itu jawaban adek untuk bagian a

SH1 $010 \mathrm{~S}$ : Iya kak.

Berdasarkan jawaban dan hasil wawancara di atas diperoleh informasi bahwa SH melakukan kesalahan konsep perkalian matriks yaitu mengalikan baris dan kolom tapi hanya mengalikan $6 \times 1,-4 \times 7,-3 \times 2,3 \times 8,5 \times 3,2 \times 9(\mathrm{SH} 1006 \mathrm{~S})$, seharusnya jawaban konsep perkalian matriks yang benar adalah baris pertama pada matriks B dikali dengan kolom pertama pada matriks A. Kemudian SH melakukan kesalahan tidak memahami konsep rumus perkalian matriks yaitu hasil perkalian matriks ordonya $2 \times 3$ dan kesalahan saat melakukan perhitungan yaitu perkalian $-3 \times 2=6$ (SH1 $008 \mathrm{~S}$ ). Jawaban yang benarnya untuk konsep rumus perkalian matriks adalah hasil perkalian matriks ordo 3 $\times 3$ dan jawaban yang benar untuk perhitungan adalah $-3 \times 2=-6$.

Jawaban Subjek Laki-laki (SH) Pada nomor 1 bagian b

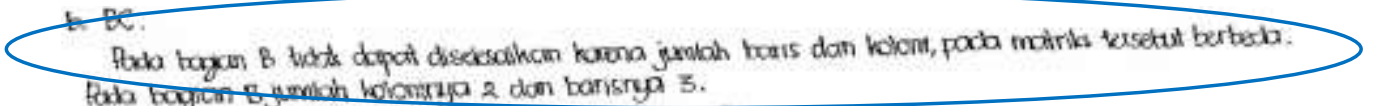

Gambar 2. Jawaban SH nomor 1 bagian b

Peneliti melakukan wawancara untuk memperoleh informasi lebih lanjut tentang kesalahan yang dilakukan SH. Berikut petikan hasil wawancara peneliti dengan SH :

SH1 $002 \mathrm{~S}$ : Pada bagian b ini saya langsung tulis matriks BC. Terus, pada bagian b tidak dapat diselesaikan karena jumlah baris dan kolom pada matriks tersebut berbeda.

SH1 $003 \mathrm{P}$ : Berbeda bagaimana dek ?

SH1 $004 \mathrm{~S}$ : Pada bagian B jumlah kolomnya 2 dan pada barisnya 3

SH1 005 P : Oh, begitu.

SH1 $006 \mathrm{~S}$ : Iya.

SH1 $007 \mathrm{P}$ : Itu adek dapat dari mana ? (Sambil menunjuk alasannya dalam hasil tes)

SH1 $008 \mathrm{~S}$ : Dari pemahaman saya kak.

Berdasarkan jawaban dan hasil wawancara di atas diperoleh informasi bahwa $\mathrm{SH}$ melakukan kesalahan tidak memahami konsep rumus perkalian matriks, karena $\mathrm{SH}$ menjelaskan bahwa pada bagian ini tidak dapat diselesaikan karena jumlah baris dan kolom pada matriks tersebut berbeda. Pada bagian B jumlah kolomnya 2 dan pada barisnya 3 
(SH1 002 S) dan (SH1 $004 \mathrm{~S}$ ). Jawaban yang sebenarnya matriks $B$ dan $A$ tidak bisa dikalikan karena jumlah kolom pada matriks $B$ tidak sama dengan jumlah baris pada matriks $A$. ( Syarat sebuah matriks dapat dikalikan jika jumlah kolom pada matriks pertama sama dengan jumlah baris pada matriks kedua ).

Jawaban Subjek Laki-laki (SH) Pada nomor 2 bagian a, b dan c

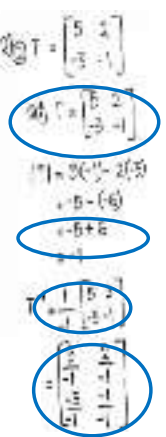

Gambar 3. Jawaban SH nomor 2 bagian a
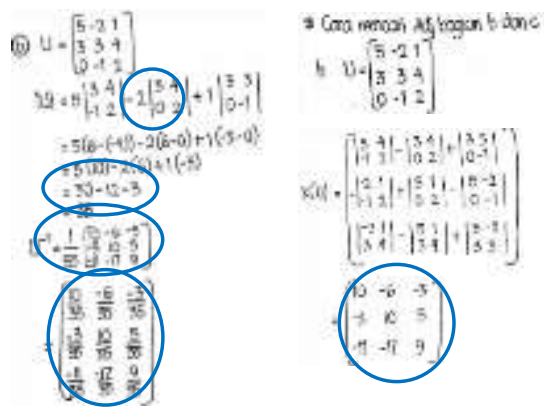

Gambar 4. Jawaban SH nomor 2 bagian $b$

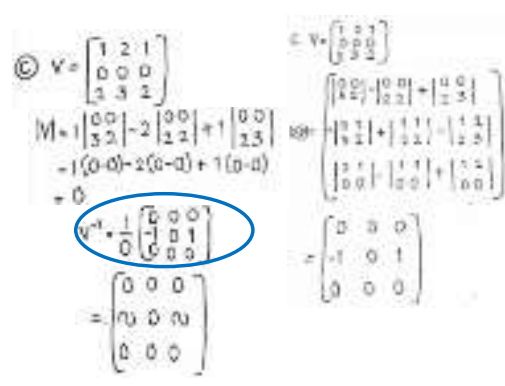

Gambar 5. Jawaban SH nomor 2 bagian $\mathrm{c}$

Peneliti melakukan wawancara untuk memperoleh informasi lebih lanjut tentang kesalahan yang dilakukan SH untuk soal nomor 2 bagian a pada gambar 3. Berikut petikan hasil wawancara peneliti dengan SH :

SH1 $001 \mathrm{P}$ : Untuk soal nomor 2 bagian a, coba jelaskan jawaban ade ?

SH1 $002 \mathrm{~S}$ : Disoal sudah diketahui matriks T, yaitu $\left[\begin{array}{cc}5 & 2 \\ -3 & -1\end{array}\right]$

SH1 $003 \mathrm{P} \quad$ : Iya terus bagaimana dek?

SH1 $004 \mathrm{~S}$ : Disini untuk mencari adjoinnya, kita lihat pada matriks T (sambi menunjuk matriks T).

SH1 $005 \mathrm{P}$ : Terus bagaimana lagi dek ?

SH1 $006 \mathrm{~S}$ : Terus kita cari determinannya, cara mencari determinan ini dengan cara $5 \times$ $(-1)-2 \times(-3)$ jadi hasilnya $(-5)-(-6)$ kemudian disederhanakan menjadi ($5)+6=-1$

SH1 $007 \mathrm{P}$ : Oh begitu dek, menurut ade itu benar atau salah ?

SH1 $008 \mathrm{~S}$ : Menurut pemahaman saya benar ka.

SH1 $009 \mathrm{P}$ : Oh iya dek, untuk selanjutnya bagaimana ade mencari inversnya ?

SH1 010 S : Caranya disini $\mathrm{T}^{-1}=\frac{1}{-1},-1$ ini diperoleh dari hasil determinannya (sambil menunjuk -1), kemudian dikali dengan adjoinnya yaitu 5, -3, 2, -1, sehingga hasilnya $\frac{5}{-1}, \frac{-3}{-1}, \frac{2}{-1}, \frac{-1}{-1}$.

Berdasarkan jawaban dan hasil wawancara di atas diperoleh informasi bahwa SH melakukan kesalahan tidak memahami konsep adjoin pada matriks, karena menjelaskan bahwa adjoin $\mathrm{T}$ sama saja dengan matriks $\mathrm{T}\left[\begin{array}{cc}5 & 2 \\ -3 & -1\end{array}\right]$ ( $\left.\mathrm{SH} 1004 \mathrm{~S}\right)$. Kemudian SH melakukan kesalahan perhitungan karena menjelaskan $5 \times(-1)-2 \times(-3)$ jadi hasilnya $(-5)$ $-(-6)$ kemudian disederhanakan menjadi $(-5)+6=-1$ (SH1 006 S) dan (SH1 008 S). Selanjutnya SH melakukan kesalahan tidak menerapkan rumus invers, SH menjelaskan bahwa langsung menuliskan $\mathrm{T}^{-1}=\frac{1}{-1}$, selanjutnya $\mathrm{SH}$ menjelaskan bahwa -1 diperoleh dari 
determinannya kemudian dikalikan dengan adjoinnya 5, -3, 2, -1 padahal adjoinnya salah. SH juga melakukan kesalahan tidak menyederhanakan, karena SH menjelaskan langsung menulis hasilnya yaitu $\frac{-5}{1}, \frac{2}{1}, \frac{8}{1}, \frac{-3}{1}(\mathrm{SH} 1010 \mathrm{~S})$ dan (SH1 $\left.012 \mathrm{~S}\right)$.

Peneliti melakukan wawancara untuk memperoleh informasi lebih lanjut tentang kesalahan yang dilakukan SH untuk soal nomor 2 bagian b pada gambar 4. Berikut petikan hasil wawancara peneliti dengan SH :

SH1 $001 \mathrm{P}$ : Untuk soal selanjutnya, bagaimana cara penyelesaian bagian $\mathrm{b}$ dek ?

SH1 $002 \mathrm{~S}$ : Diketahui matriks U pada soal, sekarang kita mencari determinannya.

SH1 $003 \mathrm{P}$ : Bagaimana cara mencari determinannya dek ?

SH1 004 S : caranya kak kita ambil 5 kemudian kita kalikan. $5\left|\begin{array}{cc}3 & 4 \\ -1 & 2\end{array}\right|-2\left|\begin{array}{ll}3 & 4 \\ 0 & 2\end{array}\right|+$ $1\left|\begin{array}{cc}3 & 3 \\ 0 & -1\end{array}\right|$ kemudian kita selesaikan $5(6-(-4))-2(6-0)+1(-3-0)$ sehingga hasilnya $5(10)-2(6)+1(-3)$ dan hasilnya lagi $50-12-3=35$.

SH1 $005 \mathrm{P}$ : Hmee, jadi itu apanya?

SH1 $006 \mathrm{~S}$ : Determinannya kak.

SH1 $007 \mathrm{P}$ : Selanjutnya apanya lagi?

SH1 $008 \mathrm{~S}$ : Selanjutnya mencari inversnya, invers ini $\frac{1}{35}, 35$ ini didapatkan dari determinannya kak (sambil menunjuk 35).

SH1 $009 \mathrm{P} \quad$ : Terus bagaimana lagi dek?

SH1 010 S : Terus selanjutnya $\frac{1}{35}$ dikalikan adjoin yaitu $10,-3,-11,-6,10,-17,-3,5,9$, sehingga penyelesaiannya $\frac{10}{35}, \frac{-3}{35}, \frac{-11}{35}, \frac{-6}{35}, \frac{10}{35}, \frac{-17}{35}, \frac{-3}{35}, \frac{5}{35}, \frac{9}{35}$.

SH1 $011 \mathrm{P}$ : Bagaimana mencari adjoinnya dek ?

SH1 $012 \mathrm{~S}$ : Dengan cara mengalikan silang untuk baris pertama seperti ini $\left|\begin{array}{cc}3 & 4 \\ -1 & 2\end{array}\right|$ $\left|\begin{array}{ll}3 & 4 \\ 0 & 2\end{array}\right|+\left|\begin{array}{cc}3 & 3 \\ 0 & -1\end{array}\right|$, untuk baris ke dua $-\left|\begin{array}{cc}-2 & 1 \\ -1 & 2\end{array}\right|+\left|\begin{array}{cc}5 & 1 \\ 0 & 2\end{array}\right|-\left|\begin{array}{ll}5 & 1 \\ 0 & 2\end{array}\right|$, untuk baris ke tiga yaitu $\left|\begin{array}{cc}-2 & 1 \\ 3 & 4\end{array}\right| \quad-\left|\begin{array}{ll}5 & 1 \\ 3 & 4\end{array}\right| \quad+\left|\begin{array}{cc}5 & -2 \\ 3 & 3\end{array}\right|$ (sambil menunjuk)

SH1 $013 \mathrm{P}$ : Selanjutnya bagaimana dek?

SH1 014 S : Selanjutnya diselesaikan menjadi yaitu untuk baris pertama 10, -6, -3, untuk baris kedua $-3,10,5$, untuk baris ketiga yaitu $-11,-17,9$.

Berdasarkan jawaban dan hasil wawancara di atas diperoleh informasi bahwa SH melakukan kesalahan dalam melakukan perhitungan pada saat mencari determinan pada matriks, SH menulis - $2\left|\begin{array}{ll}3 & 4 \\ 0 & 2\end{array}\right|$ yang seharusnya di depan (-2) ada tanda (-) sehingga pada hasil akhirnya salah dan SH menulis $50-12$ - 3 = 35 (SH1 004 S) dan (SH1 006 S). SH melakukan kesalahan tidak menerapkan rumus invers, hal itu terlihat saat SH menjelaskan dan langsung menuliskan $\frac{1}{35}$, dan menurutnya 35 ini didapatkan dari determinannya dan kemudian dikalikan $10,-3,-11,-6,10,-17,-3,5,9$ padahal adjoinnya salah, sehingga hasilnya $\frac{10}{35}, \frac{-3}{35}, \frac{-11}{35}, \frac{-6}{35}, \frac{10}{35}, \frac{-17}{35}, \frac{-3}{35}, \frac{5}{35}, \frac{9}{35}$, kesalahan berikutnya yang dilakukan oleh SH yaitu kesalahan tidak menyederhanakan, terlihat SH hanya menuliskan $\frac{5}{35}$ tapi SH tidak menyederhanakannya (SH1 008 S) dan (SH1 010 S). 
Peneliti melakukan wawancara untuk memperoleh informasi lebih lanjut tentang kesalahan yang dilakukan SH untuk soal nomor 2 bagian c pada gambar 5. Berikut petikan hasil wawancara peneliti dengan $\mathrm{SH}$ :

SH1 $001 \mathrm{P}$ : Coba jelaskan dulu jawaban bagian c dek ?

SH1 $002 \mathrm{~S}$ : Dibagian c ini sudah diketahui matriks V

$\mathrm{SH} 1003 \mathrm{P}$ : Iya terus?

SH1 $004 \mathrm{~S}:$ Untuk mencari determinannya kita kalikan $1\left|\begin{array}{ll}0 & 0 \\ 3 & 2\end{array}\right|-2\left|\begin{array}{ll}0 & 0 \\ 2 & 2\end{array}\right|+1\left|\begin{array}{ll}0 & 0 \\ 2 & 3\end{array}\right|$, sehingga kita dapat penyelesaiannya $1(0-0)-2(0-0)+1(0-0)$ dan hasil akhirnya 0

SH1 $005 \mathrm{P}$ : Selanjutnya apa lagi dek ?

SH1 $006 \mathrm{~S}$ : Selanjutnya untuk mencari inversnya jadi $\frac{1}{0}$ dikalikan dengan adjoin. Adjoinnya $0,-1,0,0,0,0,0,1,0$. Kemudian hasilnya $0, \infty, 0,0,0,0,0, \infty$, 0 .

SH1 $007 \mathrm{P}$ : Oh, begitu hasilnya dek

SH1 $008 \mathrm{~S}$ : iya kak.

SH1 $009 \mathrm{P}$ : Bagaimana mencari adjoinnya dek?

SH1 $010 \mathrm{~S} \quad$ : Dengan cara mengalikan silang baris pertama $\left|\begin{array}{ll}0 & 0 \\ 3 & 2\end{array}\right| \quad-\left|\begin{array}{ll}0 & 0 \\ 2 & 2\end{array}\right|+$ $\left|\begin{array}{ll}0 & 0 \\ 2 & 3\end{array}\right|$, untuk baris ke dua $-\left|\begin{array}{ll}2 & 1 \\ 3 & 2\end{array}\right|+\left|\begin{array}{ll}1 & 1 \\ 2 & 2\end{array}\right|-\left|\begin{array}{ll}1 & 2 \\ 2 & 3\end{array}\right|$, untuk baris ke tiga yaitu $\left|\begin{array}{ll}2 & 1 \\ 0 & 0\end{array}\right|-\left|\begin{array}{ll}1 & 1 \\ 0 & 0\end{array}\right|+\left|\begin{array}{ll}1 & 2 \\ 0 & 0\end{array}\right|$ (sambil menunjuk).

Berdasarkan jawaban dan hasil wawancara di atas diperoleh informasi bahwa SH melakukan kesalahan konsep invers pada matriks, karena SH menjelaskan bahwa SH tetap mencari invers dari matriks $\mathrm{V}$ padahal determinan $\mathrm{V}$ sama dengan 0 , sehingga pada hasil akhirnya ada nilai yang tak terdefinisi. Matriks $V$ ini tidak mempunyai invers dikarenakan determinan pada matriks $V$ sama dengan 0. ( Syarat sebuah matriks mempunyai invers adalah determinan suatu matriks tidak sama dengan 0 ).

Jawaban Subjek Perempuan (DS) Pada nomor 1 bagian a

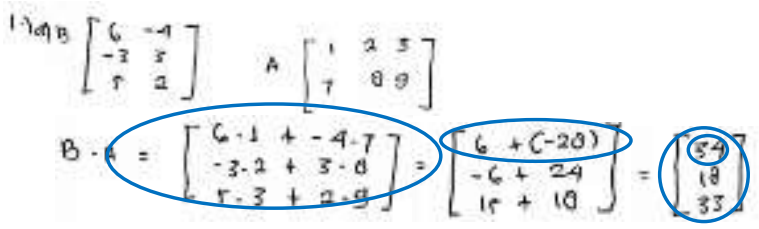

Gambar 6. Jawaban DS nomor 1 bagian a

Peneliti melakukan wawancara untuk memperoleh informasi lebih lanjut tentang kesalahan yang dilakukan DS. Berikut petikan hasil wawancara peneliti dengan DS :

DS1 $007 \mathrm{P}$ : Bagaimana adek selesaikan nomor 1 bagian a ?

DS1 $008 \mathrm{~S}$ : Kalau saya saya kalikan baris kali kolom

DS1 $009 \mathrm{P}$ : Bagaimana caranya dek?

DS1 $010 \mathrm{~S}$ : Disini saya kalikan matriks B dengan A yaitu $\left[\begin{array}{c}6.1+(-4) .7 \\ -3.2+3.8 \\ 5.3+2.9\end{array}\right]$.

DS1 $011 \mathrm{P}$ : Selanjutnya bagaimana lagi dek ? 
DS1 $012 \mathrm{~S}$ : Terus hasil dari perkalian itu saya jumlahkan $\left[\begin{array}{c}6+(-28) \\ -6+24 \\ 15+18\end{array}\right]$.

DS1 $013 \mathrm{P} \quad$ : Terus dek ?

DS1 $014 \mathrm{~S}$ : Terus hasil penjumlahanya menjadi $\left[\begin{array}{l}34 \\ 18 \\ 33\end{array}\right]$.

DS1 $015 \mathrm{P}$ : Oh begitu hasilnya ?

DS1 $016 \mathrm{~S}$ : Iye kak.

Berdasarkan jawaban dan hasil wawancara di atas diperoleh informasi bahwa DS melakukan kesalahan konsep perkalian matriks yaitu mengalikan baris dan kolom tapi hanya mengalikan $6 \times 1+(-4) \times 7,-3 \times 2+3 \times 8,5 \times 3+2 \times 9$ (DS1 008 S) dan (DS1 $010 \mathrm{~S}$ ). Kemudian DS melakukan kesalahan saat melakukan perhitungan yaitu penjumlahan $6+(-28)=34$ dan kesalahan tidak memahami konsep rumus perkalian matriks yaitu hasil perkalian matriks ordonya $3 \times 1(\mathrm{DS} 1012 \mathrm{~S})$ dan (DS1 014 S) .

\section{Jawaban Subjek Perempuan (DS) Pada nomor 1 bagian $b$}

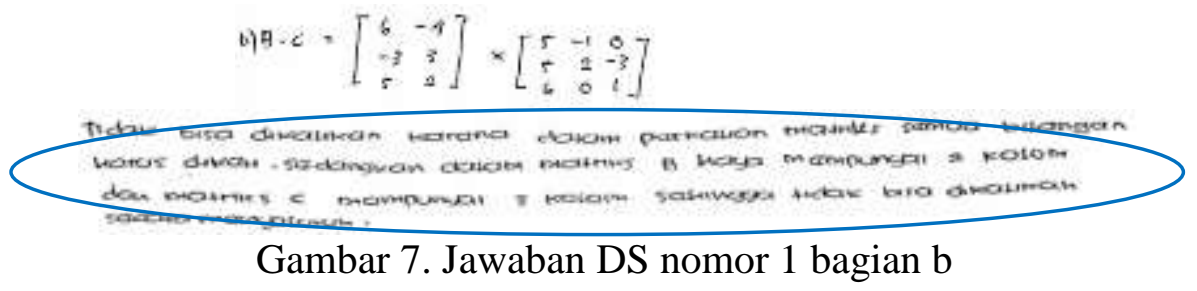

Peneliti melakukan wawancara untuk memperoleh informasi lebih lanjut tentang kesalahan yang dilakukan DS. Berikut petikan hasil wawancara peneliti dengan DS :

DS1 $001 \mathrm{P}$ : Selanjutnya untuk bagian b, bagaimana adek selesaikan ?

DS1 $002 \mathrm{~S}$ : Ehmm, kalau menurut saya disini tidak bisa diselesaikan

DS1 $003 \mathrm{P}$ : Kenapa bisa dek ?

DS1 $004 \mathrm{~S}$ : Karena dalam perkalian matriks semua bilangan harus dikali, sedangkan matriks $\mathrm{B}$ hanya mempunyai 2 kolom dan matriks $\mathrm{C}$ mempunyai 3 kolom sehingga tidak bisa dikalikan secara menyeluruh.

DS1 $005 \mathrm{P} \quad$ : Oh begitu dek, jadi tidak bisa dikalikan menyeluruh ya.

DS1 $006 \mathrm{~S}$ : Iya kak.

Berdasarkan jawaban dan hasil wawancara di atas diperoleh informasi bahwa DS melakukan kesalahan tidak memahami konsep rumus perkalian matriks, karena DS menjelaskan bahwa pada bagian ini tidak dapat diselesaikan karena dalam perkalian matriks semua bilangan harus dikali, sedangkan matriks B hanya mempunyai 2 kolom dan matriks C mempunyai 3 kolom sehingga tidak bisa dikalikan secara menyeluruh. (DS1 004 S) dan (DS1 $006 \mathrm{~S}$ ).

\section{Jawaban Subjek Perempuan (DS) Pada nomor 2 bagian a, b dan c}

Peneliti melakukan wawancara untuk memperoleh informasi lebih lanjut tentang kesalahan yang dilakukan DS untuk soal nomor 2 bagian a pada gambar 8 . Berikut petikan hasil wawancara peneliti dengan DS :

DS1 $001 \mathrm{P}$ : Kemudian kita lanjut ke soal nomor 2 bagian a, apa yang adek bisa pahami ? 
DS1 $002 \mathrm{~S}$ : Diketahui matriks T kak yaitu $\left[\begin{array}{cc}5 & 2 \\ -3 & -1\end{array}\right]$

DS1 $003 \mathrm{P}$ : Terus bagaimana adek selesaikan?

DS1 $004 \mathrm{~S}$ : Ehm, disini diketahui matriks $\mathrm{T}$ kak yaitu $\left[\begin{array}{cc}5 & 2 \\ -3 & -1\end{array}\right]$, terus dicari determinannya.

DS1 $005 \mathrm{P}$ : Terus bagaimana mencari determinannya ?

DS1 $006 \mathrm{~S}$ : cara mencari determinan dikali dia 5.(-1) - 2.(-3) hasilnya itu $-5-(-6)$ sama dengan $-5+6$ hasilnya -1

DS1 $007 \mathrm{P}$ : Oh begitu dek, selanjutnya apanya lagi dek dicari ?

DS1 $008 \mathrm{~S} \quad:$ T invers, disini rumusnya $T^{1}=\frac{1}{|T|}$ adj $T$

DS1 $009 \mathrm{P}$ : Selanjutnya bagaimana?

DS1010 S : Kan sudah ditau tadi determinannya, tinggal dimasukkan saja $\frac{1}{|T|}$ adjoin $T$, Adjoin $\mathrm{T}$ dari matriks $\mathrm{T}$ yang diketahui tadi

DS1 $011 \mathrm{P}$ : Terus bagaimana lagi dek, untuk inversnya ?

DS1 $012 \mathrm{~S}:$ Ini $\frac{1}{|T|}$

DS1 $013 \mathrm{P} \quad$ : Terus bagaimana adek selesaikan inversnya ?

DS1 $014 \mathrm{~S}:$ Dikalik kak, $\frac{1}{-1}\left[\begin{array}{cc}5 & 2 \\ -3 & -1\end{array}\right]$ dan hasilnya $\left[\begin{array}{cc}5 & 2 \\ -3 & -1\end{array}\right]$

DS1 $015 \mathrm{P}$ : Oh begitu dek, bagaimana tadi pembagiannya dek ?

DS1 $016 \mathrm{~S}$ : Begini kak, kan 1 kali 5 sama dengan 5 terus dibagi -1

DS1 017 P : Oh, begitu dek.

DS1 $018 \mathrm{~S}$ : Iya kak.

Berdasarkan jawaban dan hasil wawancara di atas diperoleh informasi bahwa DS melakukan kesalahan perhitungan karena menjelaskan $-5+6$ hasilnya -1 (DS1 006 S) dan (DS1 008 S), jawaban yang benar untuk konsep penjumlahanya yaitu $-5+6=1$. DS juga melakukan kesalahan tidak memahami konsep adjoin pada matriks, karena menjelaskan bahwa adjoin $\mathrm{T}$ itu diketahui dari matriks $\mathrm{T}\left[\begin{array}{cc}5 & 2 \\ -3 & -1\end{array}\right]$ (DS1 $\left.012 \mathrm{~S}\right)$ dan (DS1 $\left.014 \mathrm{~S}\right)$, jawaban yang benar untuk adjoin matriks T yaitu $\left[\begin{array}{cc}-1 & -2 \\ 3 & 5\end{array}\right]$.

Peneliti melakukan wawancara untuk memperoleh informasi lebih lanjut tentang kesalahan yang dilakukan DS untuk soal nomor 2 bagian b pada gambar 9. Berikut petikan hasil wawancara peneliti dengan DS :

DS1 $001 \mathrm{P}$ : Oke selanjutnya bagian $\mathrm{b}$, coba jelaskan jawaban adek untuk bagian $\mathrm{b}$ ?

DS1 $002 \mathrm{~S}$ : Disini kan matriks U sudah diketahui yaitu $\left[\begin{array}{ccc}5 & -2 & 1 \\ 3 & 3 & 4 \\ 0 & -1 & 2\end{array}\right]$.

DS1 $003 \mathrm{P} \quad$ : Terus dek bagaimana lagi ?

DS1 004 S : Disini kita mencari determinannya dengan cara $5\left|\begin{array}{cc}3 & 4 \\ -1 & 2\end{array}\right|-(-2)\left|\begin{array}{ll}3 & 4 \\ 0 & 2\end{array}\right|+1$ $\left|\begin{array}{cc}3 & 3 \\ 0 & -1\end{array}\right|$

DS1 $005 \mathrm{P}$ : Jadi selanjutnya bagaimana lagi?

DS1 $006 \mathrm{~S}$ : Selanjutnya itu kita kalikan yaitu $5(6-(-4))+2(6-0)+1(-3-0)$, hasilnya lagi $5(6+4)+2(6)+(-3)$, terus hasilnya lagi $5(10)+12+(-3)$ jadi 
$50+12+(-3)=50+15$ hasilnya 65 .

DS1 $007 \mathrm{P} \quad$ : Bagaimana cara mencari adjoinnya dek ?

DS1 $008 \mathrm{~S}:$ caranya itu dikalikan yaitu untuk baris pertama seperti ini $\left|\begin{array}{cc}3 & 4 \\ -1 & 2\end{array}\right|$ $\left|\begin{array}{ll}3 & 4 \\ 0 & 2\end{array}\right|+\left|\begin{array}{cc}3 & 3 \\ 0 & -1\end{array}\right|$, untuk baris kedua $-\left|\begin{array}{cc}-2 & 1 \\ -1 & 2\end{array}\right|+\left|\begin{array}{cc}5 & 1 \\ 0 & 2\end{array}\right|-\left|\begin{array}{ll}5 & 1 \\ 0 & 2\end{array}\right|$, untuk baris ketiga yaitu $\left|\begin{array}{cc}-2 & 1 \\ 3 & 4\end{array}\right|-\left|\begin{array}{ll}5 & 1 \\ 3 & 4\end{array}\right|+\left|\begin{array}{cc}5 & -2 \\ 3 & 3\end{array}\right|$ (sambil menunjuk)

DS1 $009 \mathrm{P} \quad$ : Terus bagaimana lagi ?

DS1 $010 \mathrm{~S}$ : Terus hasilnya yaitu untuk baris pertama 10, -6, -3, untuk baris kedua 3, 10, -10 , untuk baris ketiga yaitu $-5,-17,21$.

DS1 $011 \mathrm{P}$ : Saya tanya dek, bagaimana adek dapat 10 ini ? (sambil menunjuk)

DS1 $012 \mathrm{~S}$ : Dikali silang kak, antara $3 \times 2-4 \times(-1)=6+4$ hasilnya 10 kak.

DS1 $013 \mathrm{P}$ : Oh begitu, terus selanjutnya apa lagi dek, setelah habis mencari adjoin ?

DS1 $014 \mathrm{~S} \quad$ : Kemudian kita masukkan semua kedalam rumus $U^{-1}=\frac{1}{|U|}$ adj $U$

DS1 $015 \mathrm{P}$ : Baru bagaimana lagi dek ?

DS1016S : Terus yang diperoleh tadi dikasi masuk kedalam rumus, jadi $\frac{1}{65}$ $\left[\begin{array}{ccc}10 & -6 & -3 \\ 3 & 10 & -10 \\ -5 & -17 & 21\end{array}\right]$

DS1 $017 \mathrm{P} \quad$ : Terus dek?

DS1 $018 \mathrm{~S}:$ Hasil kalinya itu $\frac{10}{65}, \frac{-6}{65}, \frac{-3}{65}, \frac{3}{65}, \frac{10}{65}, \frac{-10}{65}, \frac{-5}{65}, \frac{-17}{65}, \frac{21}{65}$.

DS1 019 P : Oh oke dek.

Berdasarkan jawaban dan hasil wawancara di atas diperoleh informasi bahwa DS melakukan kesalahan perhitungan yakni pada kofaktor U yang bagian $-\left|\begin{array}{ll}5 & 1 \\ 0 & 2\end{array}\right|$ dan bagian $\left|\begin{array}{cc}-2 & 1 \\ 3 & 4\end{array}\right|$ dan masing-masing hasilnya yaitu -10 dan -5 (DS1 010 S) dan (DS1 012 S). Selanjutnya DS melakukan kesalahan konsep adjoin, karena disini DS menuliskan kalau adjoin $U$ adalah kofaktor dari $U$ yaitu $\left[\begin{array}{ccc}10 & -6 & -3 \\ 3 & 10 & -10 \\ -5 & -17 & 21\end{array}\right]$ (DS1 $018 \mathrm{~S}$ ).

Peneliti melakukan wawancara untuk memperoleh informasi lebih lanjut tentang kesalahan yang dilakukan DS untuk soal nomor 2 bagian c pada gambar 10. Berikut petikan hasil wawancara peneliti dengan DS :

DS1 $001 \mathrm{P} \quad$ : Kemudian kita ke bagian c, bagaimana adek menjawabnya ?

DS1 $002 \mathrm{~S}$ : Disini sudah diketahui matriks V yaitu $\left[\begin{array}{lll}1 & 2 & 1 \\ 0 & 0 & 0 \\ 2 & 3 & 2\end{array}\right]$.

DS1 $003 \mathrm{P}$ : Terus dek, bagaimana lagi?

DS1 $004 \mathrm{~S} \quad$ : Terus kita cari determinannya, caranya dikalikan seperti ini kak $1\left|\begin{array}{ll}0 & 0 \\ 3 & 2\end{array}\right|-2$ $\left|\begin{array}{ll}0 & 0 \\ 2 & 2\end{array}\right|+1\left|\begin{array}{ll}0 & 0 \\ 2 & 3\end{array}\right|$ (sambil menunjuk), terus hasil kalinya itu $1(0-0)-2($ $0-0)+1(0-0)$, jadi hasilnya lagi $1(0)-2(0)+(0)$ hasil akhirnya 0

DS1 $005 \mathrm{P}$ : Setelah itu bagaimana lagi dek?

DS1 $006 \mathrm{~S}$ : Setelah itu saya mencari $\mathrm{V}^{-1}$, tapi disini kita cari dulu adjoin V 
DS1 $007 \mathrm{P}$ : Bagaimana caranya dek?

DS1 $008 \mathrm{~S} \quad$ : Caranya itu dikalikan untuk baris pertama $\left|\begin{array}{ll}0 & 0 \\ 3 & 2\end{array}\right|-\left|\begin{array}{ll}0 & 0 \\ 2 & 2\end{array}\right|+\left|\begin{array}{ll}0 & 0 \\ 2 & 3\end{array}\right|$, untuk baris ke dua $-\left|\begin{array}{ll}2 & 1 \\ 3 & 2\end{array}\right|+\left|\begin{array}{ll}1 & 1 \\ 2 & 2\end{array}\right|-\left|\begin{array}{ll}1 & 2 \\ 2 & 3\end{array}\right|$, untuk baris ke tiga yaitu $\left|\begin{array}{ll}2 & 1 \\ 0 & 0\end{array}\right|-\left|\begin{array}{ll}1 & 1 \\ 0 & 0\end{array}\right|+\left|\begin{array}{ll}1 & 2 \\ 0 & 0\end{array}\right|$ (sambil menunjuk)

DS1 $009 \mathrm{P} \quad$ : Bagaimana tadi ade cari ini (sambil menunjuk $\left|\begin{array}{ll}0 & 0 \\ 3 & 2\end{array}\right|$ )

DS1 $010 \mathrm{~S}$ : Dikali silang kak $0 \times 2-0 \times 3$ hasilnya 0

DS1 $011 \mathrm{P}$ : Baru bagaimana lagi dek ?

DS1 $012 \mathrm{~S}$ : Dimasukkan menjadi $\frac{1}{0}$ kali $\left[\begin{array}{ccc}0 & -1 & 0 \\ 0 & 0 & 0 \\ 0 & 1 & 0\end{array}\right]$

DS1 $013 \mathrm{P} \quad$ : Terus dek?

DS1 $014 \mathrm{~S}:$ Hasil perkalian tadi menjadi $\frac{0}{0}, \frac{-1}{0}, \frac{0}{0}, \frac{0}{0}, \frac{0}{0}, \frac{0}{0}, \frac{0}{0}, \frac{1}{0}, \frac{0}{0}$ dan semua hasilnya tak terdefinisi.

DS1 $015 \mathrm{P}$ : Kenapa bisa dek ?

DS1 $016 \mathrm{~S}$ : Karena $\frac{0}{0}$ itu hasilnya tak terdefinisi.

Berdasarkan jawaban dan hasil wawancara di atas diperoleh informasi bahwa DS melakukan kesalahan konsep invers pada matriks, karena terlihat dari penjelasanya kalau DS tetap mencari invers dari matriks (V DS1 004 S) dan (DS1 014 S) padahal determinan $\mathrm{V}$ sama dengan 0 , sehingga pada hasil akhirnya ada nilai yang tak terdefinisi.

Berikut jawaban DS untuk soal nomor 2 bagian a, b dan c

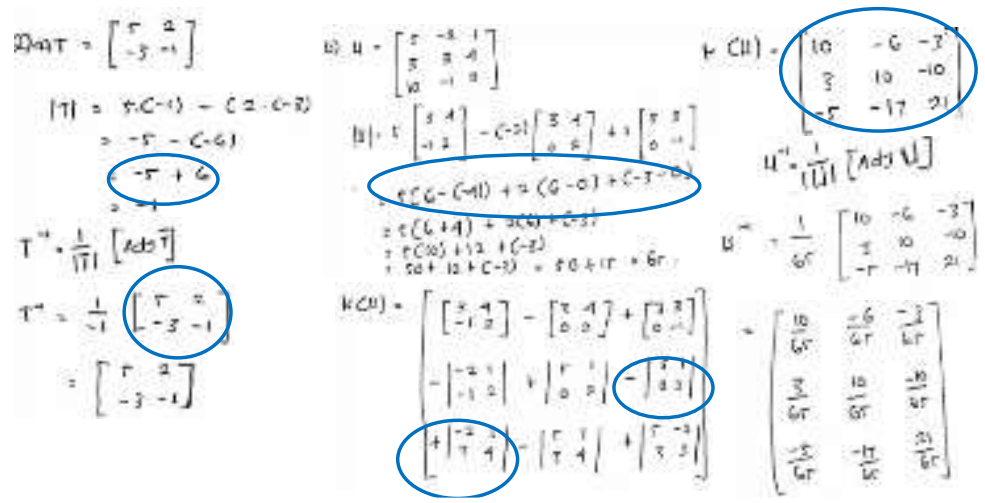

Gambar 8. Jawaban DS nomor 2 bagian a
Gambar 9. Jawaban DS nomor 2 bagian $b$

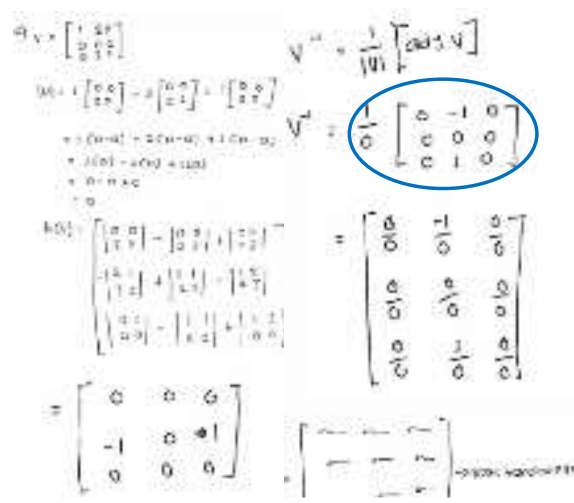

Gambar 10. Jawaban DS nomor 2 bagian $\mathrm{c}$

\section{PEMBAHASAN}

Kesalahan dilakukan SH dan DS yaitu kesalahan konsep perkalian matriks. SH melakukan kesalahan konsep perkalian matriks karena SH langsung mengalikan matriks B dengan A tapi cara mengalinya salah, SH mengalikan elemen baris pertama dan kolom pertama pada matriks B dengan baris pertama kolom pertama pada matriks A. DS melakukan kesalahan konsep perkalian matriks karena DS langsung mengalikan dan menjumlahkan kedua matriks tapi perkalian dan penjumlahanya salah. DS mengalikan elemen baris pertama dan kolom pertama pada matriks B dengan baris pertama kolom 
pertama pada matriks A kemudian dijumlahkan dengan baris kedua kolom dua kali baris kedua kolom pertama. Kesalahan tersebut merupakan kekeliruan yang dilakukan oleh siswa. Sejalan dengan pendapat Ramlah (2016) yang menyatakan kesalahan konsep perkalian matriks dikarenakan kekeliruan yang dilakukan siswa, kebanyakan siswa berfikir bahwa suatu matriks dapat dikalikan hanya jika ordo dari matriks yang akan dikalikan itu sama, sehingga ketika menemukan matriks yang memiliki ordo yang berbeda siswa langsung salah ketika mengalikan entri-entrinya.

Kesalahan berikut yang dilakukan SH dan DS yaitu kesalahan tidak memahami konsep rumus perkalian matriks yang terjadi pada soal nomor 1 bagian a dan pada soal nomor 1 bagian b. SH melakukan kesalahan konsep rumus perkalian matriks karena SH langsung mengalikan antara baris dan kolom tanpa memahami konsep rumus perkalian matriks tapi hasil perkalian matriks salah, dimana hasil perkalian pada tes SH adalah ordonya 2 × 3 yang seharusnya ordo hasil perkalianya yaitu $3 \times 3$. DS melakukan kesalahan konsep rumus perkalian matriks karena langsung mengalikan antara baris dan kolom tapi salah dalam menentukan ordo hasil perkalian matriksnya. Dimana DS hasil ordo perkalian matriksnya yaitu $3 \times 1$, padahal yang seharusnya ordo hasil perkaliannya yaitu $3 \times 3$. Kesalahan ini disebabkan karena siswa belum mengerti rumus perkalian matriks. Sejalan dengan pendapat Krismantono (2016) menyatakan bahwa siswa melakukan kesalahsan dalam mencari hasil perkalian matriks karena siswa belum mengerti rumus perkalian matriks.

Kesalahan berikut yang dilakukan oleh SH dan DS yaitu kesalahan konsep invers matriks. SH melakukan kesalahan konsep invers matriks, karena SH tetap mencari invers dari matriks $\mathrm{V}$ padahal determinan matriks $\mathrm{V}$ sama dengan 0 , sehingga pada hasil akhirnya ada nilai yang tak terdefinisi. DS melakukan kesalahan yang sama dengan SH yaitu kesalahan konsep invers pada matriks, karena DS tetap mencari invers dari matriks V padahal determinan $\mathrm{V}$ sama dengan 0, sehingga pada hasil akhirnya semua nilainya tak terdefinisi. Kesalahan ini disebabkan karena siswa tidak mengerti tentang syarat mencari invers matriks. Sejalan dengan Krismantono (2016) yang mengatakan bahwa beberapa siswa melakukan kesalahan dalam mencari invers matriks karena siswa tidak mengerti syarat mencari invers matriks.

Kesalahan lain yang dilakukan oleh SH dan DS yaitu kesalahan konsep adjoin yang terjadi pada soal nomor 2 bagian a, b dan c. SH melakukan kesalahan konsep adjoin, karena SH menuliskan lagi kalau adjoin $\mathrm{T}$ sama saja dengan matriks $\mathrm{T}$ yaitu $\left[\begin{array}{cc}5 & 2 \\ -3 & -1\end{array}\right]$. Selanjutnya DS juga melakukan kesalahan konsep adjoin, karena disini DS menuliskan lagi kalau adjoin $T$ itu sama dengan matriks $T$ yaitu $\left[\begin{array}{cc}5 & 2 \\ -3 & -1\end{array}\right]$. Kesalahan tersebut dikategorikan dalam kesalahan konsep sebagaimana yang dikemukakan Utami (2012) yang mengatakan bahwa kesalahan konsep yang dilakukan oleh siswa dalam menyelesaikan soal terjadi akibat ketidaktahuan dan ketidakpahaman siswa akan konsep, sehingga banyak konsep yang dipahami secara keliru

Kesalahan berikut yang dilakukan SH dan DS yaitu kesalahan perhitungan yang terjadi pada soal nomor 1 bagian a, nomor 2 bagian a dan c. SH melakukan kesalahan perhitungan yaitu perkalian $-3 \times 2=6$. DS melakukan kesalahan perhitungan yaitu penjumlahan $6+(-28)=34$. Kesalahan ini merupakan kesalahan operasi perhitungan yang sejalan dengan Utami (2012) bahwa kesalahan hitung yaitu kesalahan melakukan operasi hitung dalam matematika seperti menjumlah, mengurang, mengali dan membagi. 
Kesalahan berikut yaitu kesalahan tidak menerapkan rumus invers matriks dan hanya $\mathrm{SH}$ yang melakukan kesalahan ini dan terjadi pada soal nomor 2 bagian a dan b. SH melakukan kesalahan tidak menerapkan rumus invers matriks, karena SH langsung menuliskan $\mathrm{T}^{-1}=\frac{1}{-1}$ dikalikan $5,-3,2,-1$. Hal yang sama terjadi terlihat $\mathrm{SH}$ langsung menuliskan $\mathrm{U}^{-1}=\frac{1}{35}$ dikalikan $10,-3,-11,-6,10,-17,-3,5,9$. Kesalahan ini dikategorikan sebagai kesalahan konsep yang sejalan dengan Apriliawan (2015) yang menyatakan bahwa kesalahan konsep merupakan tipe kesalahan yang dilakukan siswa dalam menerapkan rumus-rumus yang diperlukan dalam menjawab soal.

Kesalahan berikut yaitu kesalahan tidak menyederhanakan. SH melakukan kesalahan tidak menyederhanakan, karena tidak menyederhanakan pembagian antara $\frac{5}{-1}, \frac{-3}{-1}$, $\frac{2}{-1}, \frac{-1}{-1}$. Kesalahan ini merupakan kesalahan prosedur pekerjaan tidak lengkap yang sejalan dengan pendapat Ramlah (2016) bahwa kesalahan prosedur tidak lengkap yang dilakukan oleh siswa yaitu tidak menyederhanakan pecahan kebentuk yang sederhana.

Kesalahan berikut yang dilakukan oleh $\mathrm{SH}$ adalah kesalahan menuliskan tanda operasi pada langkah penyelesaian. Hal itu terlihat pada saat mau mencari adjoin dimana SH tidak menuliskan tanda (-), SH hanya menuliskan $-2\left|\begin{array}{ll}3 & 4 \\ 0 & 2\end{array}\right|$, padahal yang seharusnya ada tanda (-) di depan (-2). Kesalahan tersebut merupakan kesalahan fakta yang sejalan dengan yang dikemukakan oleh Wulandari (2018) bahwa kesalahan dalam penulisan serta kesalahan tanda operasi merupakan kesalahan fakta.

\section{KESIMPULAN}

Kesalahan yang dilakukan SH dan DS yang sesuai dengan indikator kesalahan yaitu kesalahan konseptual dan prosedural. Kesalahan konseptual yang dilakukan siswa laki-laki (SH) yaitu : 1) kesalahan tidak memahami konsep rumus perkalian matriks, 2) kesalahan konsep perkalian matriks, 3) kesalahan tidak menerapkan rumus invers, 4) kesalahan konsep invers matriks dan 5) kesalahan konsep adjoin. Kesalahan prosedural yang dilakukan siswa laki-laki berupa 1) kesalahan dalam melakukan perhitungan, 2) kesalahan tidak menyederhanakan, 3) kesalahan tidak menuliskan tanda operasi pada matriks.

Kesalahan konseptual yang dilakukan siswa perempuan (DS) yaitu: 1) kesalahan tidak memahami konsep rumus perkalian matriks, 2) kesalahan konsep perkalian matriks, 3) kesalahan konsep adjoin, dan 4) kesalahan konsep invers matriks. Kesalahan prosedural yang dilakukan siswa perempuan berupa 1) kesalahan dalam melakukan perhitungan.

Dalam menyelesaikan soal matriks, antara siswa laki-laki dan siswa perempuan terdapat persamaan dan perbedaan dalam melakukan kesalahan. Adapun persamaannya antara lain yaitu: 1) kesalahan tidak memahami konsep rumus perkalian matriks, 2) kesalahan konsep perkalian matriks, 3) kesalahan konsep invers matriks dan 4) kesalahan konsep adjoin 5) kesalahan dalam melakukan perhitungan, sedangkan perbedaannya hanya siswa laki-laki saja yang melakukan antara lain yaitu : 1) kesalahan tidak menerapkan rumus invers, 2) kesalahan tidak menyederhanakan, dan 3) kesalahan tidak menuliskan tanda operasi pada matriks.

Siswa laki-laki banyak melakukan kesalahan dari pada siswa perempuan dikarenakan, siswa laki-laki tidak teliti dan terburu-buru dalam menyelesaikan soal matriks. Siswa perempuan tidak terlalu banyak melakukan kesalahan dikarenakan cenderung lebih teliti dan cermat dalam menyelesaikan soal matriks. 
Fausan, Gandung Sugita, dan Sukayasa, Profil Kesalahan ... 123

\section{SARAN}

Saran yang dapat peneliti berikan untuk mengurangi atau meminimalisir kesalahan siswa pada materi matriks yaitu : sebaiknya guru memberikan perhatian lebih pada materi matriks sebab materi tersebut paling dianggap sulit oleh siswa. Siswa hendaknya banyak melakukan latihan mengerjakan soal untuk lebih meningkatkan kemampuan pemahamannya dan meningkatkan keterampilan berhitung agar dalam menyelesaikan soal siswa tidak melakukan kesalahan lagi pada proses pembelajaran serta konsep yang dimiliki siswa bertambah banyak serta tidak lagi terjadi kesalahan dalam melakukan perhitungan.

\section{DAFTAR PUSTAKA}

Apriliawan. (2015). Analisis Kesalahan Penyelesaian Soal Uraian Matematika Siswa MTs pada pokok Bahasan Unsur-Unsur Lingkaran. Jurnal ilmiah pendidikan matematika IKIP PGRI Madiun. Vol 1 No 2. [Online].Tersedia:http://jurnal.Ikippgr.imadiu n.ac.id /index.php/jipm/article/view/480. [ 19 Mei 2019]

Asrori, M (2007). Psikologi Pembelajaran. Bandung : CV. Wacana Prima.

Jensen, E. (2008). Pembelajaran Berbasis Kemampuan Otak. Yogyakarta : PustakaPelajar.[Online].Tersedia:http://library.fip.uny.ac.id/opac/index.php?p=show_ detail\&id=4888 [ 6 Maret 2019]

Kastolan. et. al. (1992). Identifikasi Jenis-Jenis Kesalahan Menyelsaikan Soal-Soal Matematika yang Dilakukan Peserta Didik Kelas II Program Al SMA Negeri SeKotamadya Malang. Malang: IKIP Malang. [Online]. Tersedia: http//mulok.library.um.ac.id. [ 5 Maret 2019 ]Kowiyah. (2012). Kemampuan Berpikir Kritis. Jurnal Pendidikan Dasar. Vol. 3, No. 5, Hal 175-179. [Online]. Tersedia:http://download.garuda.ristekdikti.go.id/article.php.201158.Kemampuan_ Berpikir_Kritis. [25Januari 2019]

Krismantono, R.R. Purnami, A.S. (2016). Analisis kesalahan dalam menyelesaikan soal matematika. Jurnal Program Studi Pendidikan Matematika UST Yogyakarta. [Online].Tersedia:http://jurnal.ustjogja.ac.id./indeks.php/etnomatnesia/article/downlo $\mathrm{ad} / 2311 / 1274$ [ 19 Mei 2019]

Krutetskii, V.A. (1976). The Psychology of Mathematical Abilities in School Children. Chicago.UniversityofChicagoPress.[Online].Tersedia:https://www.researchgate.net/p ublication/270585314_The_Psychology_of_Mathematical_Abilities_in_SchoolChildren [ 16 Maret 2019]

Miles, M. B, Huberman, A. M, dan Saldana J. (2014). Qualitative Data Analisis; A Methods Soucebook Edition 3. Amerika: Sage Publications.

Newman. (1977). Identified Five Basic Steps Students Must Typically Work Through to Solve Written Word Problems. Education Public Schools. [Online].Tersedia: https://numeracyskills.com.au/newman-s-error-analysis [ 5 Maret 2019] 
Oktavianti, A. Masriyah. (2016). Identifikasi Proses Berfikir Siswa Dalam Menyelesaikan Soal Cerita Pada Materi OPerasi Aljabar Di Kelas VIII SMP Negeri 2 Madiun ditinjau Dari Perbedaan Gender. Jurnal Ilmiah Pendidikan Matematika Volume 2 No.5.[Online].Tersedia:https://jurnalmahasiswa.unesa.ac.id/index.php/mathedunesa/ [17 Januari 2019]

Ramlah. (2016). Analisis Kesalahan Siswa dalam Menyelesaikan Soal Penjumlahan dan Pengurangan Pecahan di Kelas VII SMPN Model Terpadu Madani. Jurnal Ilmiah Pendidikan Matematika. Volume 1 Nomor 2. [Online].Tersedia:http://journal.upgris. ac.id/index.php/JIPMat/article/view/1245/1082 [ 30 Januari 2019 ]

Susanto, A. (2013). Teori Belajar Dan Pembelajaran Di Sekolah Dasar. Jakarta: Kencana.

Susento. (2006). Mekanisme Interaksi Antara Pengalaman Kultural-Matematis, Proses Kognitif, dan Topangan dalam Reivensi Terbimbing. Surabaya : Unesa . [Online] . Tersedia:http://repository.uksw.edu/bitstream/123456789/9775/2/T1_202010039_Ful 1\%20text.pdf. [ 16 maret 2019 ]

Utami, W.T. (2012). Identitas Kesulitan Siswa dalam Menyelesaikan Persoalan Matematika yang Berkaitan dengan Pecahan di Kelas VII SMP Negeri 3 Ngaglik Sleman Tahun Ajaran2011/2012. E-jurnal Universitas Negeri Yogyakarta. [Online].Tersedia:http// journal.student.uny.ac.id/jurnal/artikel/471/43/180 [19 Mei 2019]

Wahbi, A. Bey, A. (2015). Analisis Kesalahan Siswa Dalam Menyelesaikan Soal Faktorisasi Suku Aljabar Ditinjau Dari Objek Matematika Pada Siswa Kelas VIII SMP Negeri 15 Kendari. Jurnal Penelitian Pendidikan Matematika Vol.3No.1.[Online].Tersedia:http://ojs.uho.ac.id/index.php/JPPM/article/view/2991/2 243 [17 Januari 2019]

Wulandari, T. Resta,E.L. (2018). Analisis Kesalahan Siswa Dalam Menyelesaikan Soal Pada Materi Lingkaran. Jurnal Pendidikan Tambusai Volume 2 Nomor 6. [Online]. Tersedia:file://C:/Users/USER/Downloads/158-Article\%20Text-290-1-10 20181211.pdf [17 Januari 2019] 